\title{
Malcolm X's the ballot or the bullet speech? Its implications for Black Liberation Theology in present-day South Africa
}

\begin{abstract}
Author:
Rothney S. Tshaka ${ }^{1}$

Affiliation:

${ }^{1}$ Department of Philosophy, Practical and Systematic

Theology, University of South Africa, South Africa

Correspondence to:

Rothney Tshaka

Email:

tshakrs@unisa.ac.za

Postal address:

Samuel Pauw Building,

Room 4-35, Preller Street,

Muckleneuk, Pretoria 0003 ,

South Africa

Dates:

Received: 08 Sept 2014

Accepted: 29 Jan. 2015

Published: 29 May 2015

How to cite this article: Tshaka, R.S., 2015, 'Malcolm X's the ballot or the bullet speech? Its implications for Black Liberation Theology in present-day South Africa', HTS Teologiese Studies/

Theological Studies 71(3),

Art. \#2819, 8 pages. http://

dx.doi.org/10.4102/hts.

v71i3.2819

\section{Copyright:}

(C) 2015. The Authors. Licensee: AOSIS

OpenJournals. This work is licensed under the Creative Commons Attribution License.
\end{abstract}

\section{Read online:}

\section{Scan this QR} code with your smart phone or mobile device to read online.
This article attempts to bring one of the greatest speeches of Malcolm $X$ back to life in the current South Africa - the year 2015. It is a year of growing frustration and extreme dissatisfaction with basic living conditions amongst the greater part of black people in the country. Recounting the influences that Malcolm X had on Black Liberation Theology in South Africa, the article proposes that Black Liberation Theology in South Africa moves away from being an inward-looking critical theology to one that identifies with the basic concerns of the most vulnerable in society. It criticises both the political and the economic hegemonies that are currently perceived to perpetuate much of apartheid's grave social ills in democratic South Africa. It calls attention to party politics that floods society with propaganda but in reality seems to have little real interest in the social well-being of the masses. In the article, the question as to what Malcolm X would have said about the current South African socioeconomic context is asked. It is clear that both structural apartheid residues as well as the pure selfish interests of the current political rulers gang up against the chances of black people ever experiencing social justice in the near future.

\section{Introduction}

This article is an attempt to bring the basic insights of a watershed speech made by Malcolm $X$ in the 1960s, his 'Ballot or the bullet' speech, into critical dialogue with the present South African context. Recognising Malcolm X's critique of white racism and his relentless call for the unity of black people against the dictates of white capitalist hegemonies, this essay will argue that the speech in question is of particular relevance to understanding the current socio-economic and political challenges facing the majority of black people in South Africa. More importantly, it challenges a Black Liberation Theology that is largely inward-looking and thus is not able to assess the current socio-economic, cultural and political conditions and to speak meaningfully to such a context. ${ }^{1}$ This article is of the view that Malcolm X's metamorphosis ${ }^{2}$ allowed him the opportunity to pause from time to time and to assess the socio-economic and political contexts in which he found himself.

This article argues that, if Black Liberation Theology (BLT) is to prove its contextual relevance in present-day South Africa, it must do two things. Firstly, it must continue to assert its rebel nature. That is to say, it must never lose sight of structural racism which in essence justified the existence of BLT as a liberation theology as a means towards understanding why God created differences. Secondly, a BLT that is not inward-looking is one that is able to make the needed assessments in present-day South Africa. This suggests that self-criticism must be encouraged in order for it to assert its contemporary relevance. It boils down to engaging critically with the current hegemonies, be they political, economic or cultural.

I propose to engage this subject in the following manner. Firstly, this article will engage with the history and impact of BLT in South Africa. This is done in order to call to task the perception that talking about race is irrelevant and out-dated 20 years into our democracy. I do this realising that Malcolm X, albeit played down in BLT reflections in the United States of America (USA) and in South Africa in particular, did indeed contribute extensively towards this theological enterprise, both in the USA and in South Africa. The article then moves on to deal with some basic insights of the speech in question. It is my view that this speech is pertinent to the current political era

\footnotetext{
1.It would be naive to suggest that the changes that were brought about by democracy in South Africa addressed the race problem of this country. This is simply because racism has been structural and systemic. Black Liberation Theology must concede to this reality. Having pointed this out, one must hasten to criticise a theological reflection like BLT when it does not seem to be able to grapple with the challenges with which black communities in particular are faced as a result purely of Black self-interest. An innovative BLT is one which recognises these challenges.
}

2.A quick reading of Malcolm $\mathrm{X}$ gives one the impression that he changed his mind on quite a few occasions. 
in which one sees politicians again canvassing for votes in neglected communities.

The article ultimately moves to engage the future of Black Liberation Theology, specifically in South Africa. This is done in a context where many are claiming that there is no need to speak about black and white in the present rainbow context. In debunking this view, the paper draws a little on the epochal work of Michelle Alexander who argues against the colour-blindness rhetoric which has seeped into all racialized communities (Alexander 2012). In the end, we ask how Malcolm X would have responded to the current South African critical era of politics.

\section{The history and impact of Black Liberation Theology in South Africa}

It is commonly held that Black Liberation Theology drew its resources from diverse realities. Black Liberation Theology emerged in South Africa during the late 1960s. As a project, it was inspired by the Civil Rights Movement in the USA, the prophetic voice of Martin Luther King $\mathrm{Jr}$, Malcolm X's critique of white racism in the USA as well as the pioneering work of James Hal Cone. It was transported from the shores of the USA to South Africa as an intellectual project which was made possible by the then University Christian Movement (UCM) in 1971. All this occurred under the directorship of Basil Moore and was first spearheaded in South Africa by Sabelo Ntwasa (De Gruchy 1997:447). Therefore from the very inception of Black Liberation Theology in South Africa, we are confronted with the apt presence of white liberals in the affairs of black people.

Black Liberation Theology was expressed under the banner of the Black Consciousness Movement of South Africa, which owes its being to students such as Steve Biko, Barney Pityana, Harry Nengwenkulu and others. These students were galvanised by the then political situation into organising themselves into a vanguard for black people's total emancipation from the political pangs into which they were plunged by white racism in South Africa. Although Black theology propagated itself chiefly through means of cell groups and ministers' caucuses, it produced some significant publications and continued into the Kairos period. ${ }^{3}$ A number of the first-generation Black theologians endeavoured to develop Black Liberation theology in relationship to their confessional traditions. Amongst these can be counted the likes as Manas Buthelezi, Desmond Tutu and Allan Boesak. This tradition was continued by theologians such as Buti Tlhagale, Takatso Mofokeng, Bonganjalo Goba and Itumeleng Mosala, to mention but a few (De Gruchy 1997:447). In mentioning Malcolm X, it becomes necessary for us to explore his understanding of white liberals in the fights against white racism. This came to be an aspect also echoed by the South African Steve Biko.

3.This period refers to the time when the Kairos document was formulated. It spelled out that it was time for churches in South Africa to say something against apartheid.
It is perhaps fair to describe Black Liberation Theology in South Africa as a rebel enterprise (Tshaka \& Makofane 2010:3). Let me explain this claim briefly. I describe Black Liberation Theology as a rebel enterprise simply because it was never made to feel welcome in academia as well as in all other South African spheres of life. Whilst apartheid theology (which must be considered as a form of contextual theology in all respects and also as a form of 'liberation theology' in its own right) was political in its very nature, Black Liberation Theology, as a response to apartheid theology, carried the brand of being political.

This became a justification for discouraging its existence by all means possible. Those who engaged this theology had to find alternative platforms where these ideals could be shared and propagated, hence the black cell groups and black ministers' caucuses. The economic disparities between black people and white people made it even more difficult for black churches to assert their independence and to openly embrace this theological hermeneutic. Some African Traditional Churches came into existence primarily because they were not comfortable with a theology and theological reflection that refused to take the black experience seriously. These churches were considered too radical and were dismissed as mere sects, not to be taken seriously by any 'proper' theological reflection.

It is worth noting that these so-called sects (African Traditional Churches) ${ }^{4}$ became a dominant perspective in the reflections of the 'very' black protagonists of Black Theology. Economically, black churches of the mainline tradition remained and still remain very dependent on the so-called white mother churches, and so, in an attempt to be at least different from the rest, there was never an intentional move to align themselves with the indigenous churches as the latter wrestled to make culture and African world views important elements in their reflections. This is so because, for Black Liberation Theology, the struggle was waged more on a political level for the perception was, I guess, that once political power has been gained the economy would simply conform to the dictates of politics. Thus not much has been done in terms of economic and cultural democracy (Cruze 1967). The fact that especially the element of culture was ignored in the struggle for the assertion of black people as human beings became one of the greatest criticisms by our West and East African counterparts (Mbiti 1993:379-384).

The fact that Black Liberation Theology was a guerrilla enterprise posed significant challenges for its endeavour at penetrating the very black communities it intended to empower. Firstly, since Black Liberation Theology was chastised as 'improper theology', the apologetics of Black Liberation Theology led to an obsession with theological method instead of dealing with the concrete particular realities of black people in South Africa. There has been no theological

4The usual reference to African tradition is problematic in a certain sense. The fact that they have been considered as sects justifies why African Traditional Churches are seen as some kind of religion. I here purposefully refer to them as churches because church for me is not only a mainline church with a congregation of believers. 
enterprise in South Africa that has been more obsessed with theological method than Black Liberation Theology, hence my statement that the early protagonists of Black Liberation Theology developed it along their confessional affiliations (Tshaka 2010:206). A clear example of this can be found in Boesak's Black and reformed (Boesak 1984).

Secondly, the question of economic dependence played a major role in the inability of this theological enterprise to permeate the black communities and in it instead turning into an elitist enterprise in some instances (Terreblanche 2005). The question of economic dependency had shown how, in the case of South Africa, a very well-meaning and imperative initiative such as Black Liberation Theology can evaporate into an elitist project that is used as a spring board to personal well-being.

When taking into account the different role players in the emergence of Black Liberation Theology in South Africa, one cannot but wonder whether the suggestions today that this theology is irrelevant were not to be expected (Villa-Vicencio 1992). To begin with, Black Liberation Theology was an initiative that, to some degree, enjoyed the patronage of some white liberals. Because of their involvement with Black Liberation Theology, some of them felt that they equally had the right to determine the direction of this theology for the future. The likes of Steve Biko remained very critical of the involvement of our white friends in the affairs of black people. His statement, 'Black man, you are on your own', gave credence to his view that white people who are sincere about structural racism can only help the black cause when they engage white racism and the privileges they enjoy in their respective circles.

It is unfortunate that the black conscious element in black theology dwindled and ultimately disappeared totally from black theological discourses in post-apartheid South Africa. This is evidenced by the move away from Black Liberation Theology to contextual theology in the late 1980s and early 1990s. The 1999 multi-event (Religion in Public Life n.d.) held in Cape Town is in my view one event organised by our white liberal friends in conjunction with some black protagonists of Black Theology to chart a new direction for critical theology. It adopted a language that is friendly to all in the new South Africa. There is in my view nothing wrong with such an approach except if the particularity of the black reality is compromised.

James Cone credits the relevance of black theological reflection to the works of both Martin Luther King Jr and Malcolm X. Whilst the former has been recognised extensively in the Americas and elsewhere, it seems that the influence of Malcolm X (henceforth referred to only as Malcolm) has not received the same kind of engagement. It is my opinion that this is not by chance. King has always been hailed as the peacemaker, the one who pickets because he is of the view that hegemonies are inherently good, and it is only a

5.Slogan coined by Steve Biko for the South African Student's organisation, SASO. matter of time that American hegemonies will accept black folk as equals. Keeping the hope alive in the much-oppressed masses is something that is encouraged by all means in the theology of King (Oates 1994). This talking and thinking is of particular significance for the real masters of societies because it makes reconciliatory talk sounds feasible. Antonio Gramsci speaks of the consent given by the oppressed, and this has a direct bearing on situations in which the oppressed believe that the hegemonies are not so bad, even if this is to their own detriment (Forgacs 2000).

Contrary to King, who dreamed positively about the American civil system, it was Malcolm who was plagued by nightmares because of the injustices which were imbedded in the American civil system because of its inherent racist design (Cone 1992). For Malcolm, reconciliation is not something that will happen because of the benevolence of white folks. No picketing and sit-ins will bring about genuine change. It is only the critical unity of black people themselves that will effect change. South Africa shares realities with the USA, especially. Like the USA, it became notorious for its treatment of black people. In fact, there is a school of thought led by Giliomee (2004:9) which is of the view that apartheid proper was imported from the USA and not from Europe as commonly held. Like the USA, South Africa also drew from the sources of Black Liberation Theology as espoused in the theologies of King and Malcolm X.

What has remained something that is of interest today is especially the speech that we wish to engage in this article. Because South Africa is governed by black people, one could be forgiven to think that the challenges faced by thousands of black people in the USA are not the same as the challenges faced by the majority in South Africa today. In fact, it will be argued in this article that the brutality of the police is something that has been inherited from white racism in South Africa and remains prevalent in present South Africa because it has been perpetuated by the white racist attitudes of apartheid South Africa.

Not only was the brutality of the white police inherited from apartheid, the same vague political language which obfuscate the realities of the majority remains in force and is now used by the current political leaders. The current political leadership banks on the vulnerability of the majority. It is therefore because of this abuse that political language seems to be tuned towards the majority only during election years. Malcolm X was aware of the fact that the real enemy is white capitalism. In the current article, I indicate clearly how Malcolm X came to see how black leaders allowed themselves to be used by this diabolical system. However, having pointed this out, Malcolm does absolve white people of their responsibility. He keeps white people responsible because he is convinced that white people in particular are also dependent on this system.

Police brutality is usually symptomatic of bigger societal ills. Malcolm spoke of this when he was interviewed by Mike Wallace on 08 June 1964. In that interview, he made it clear 
that the frustration of black people has led them not to be afraid of the police any longer (Malcolm X 1964b). On the contrary, violence has become so habitual that a reaction is elicited with the slightest provocation from one's fellow brother.

Malcolm is not alone in addressing this matter. Fanon (1965) had the following to say about the internalisation of the save mentality when he observed:

\begin{abstract}
... while the settler or the policeman has the right ... to strike the native, to insult him and to make him crawl to them, you will see the native reaching for his knife at the slightest hostile or aggressive glance cast on him by another native, for the last resort of the native is to defend his personality vis-à-vis his brother. (p. 22)
\end{abstract}

We shall to return again to this later. For now, let us consider police brutality on the masses in South Africa.

It is a well-known fact that service-delivery protests are now more rampant in South Africa than they were during the apartheid era. This is not to be misinterpreted as a justification of the apartheid era or to give it credit. On the contrary, the current service-delivery protests must be understood in the context of how legal apartheid became structural and systemic. However, it is significant that the current challenges which have nothing to do with apartheid are also engaged. These protests have become so violent that many have died. For instance, the death of Andries Tatane ${ }^{6}$ shocked the nation.

I shall be careful not to refer to the entire speech although it remains a classical speech in its own right. I shall merely point to the issues that are relevant for us in South Africa with the intention of illustrating how those in power continuously fool those on the margin of society. This is so because they remain aware of the valuable votes which place them in positions of power.

\section{A brief synopsis of the speech and its significance for the future of South Africa}

In a speech given at the Cory Methodist Church in Cleveland, Ohio on 03 April 1964, titled, 'The ballot or the bullet' (Breitman 2010:38-63), Malcolm X takes care to speak of a new generation of black people who have come of age and refuse to be told by white capitalist hegemonies what the realities are which they inhabit. In a radical way, he declares that the perpetual infantilisation of black people has to be brought to a halt. This is a speech that has been ignored to a large extent by intellectuals across the globe, and yet it has significant lessons, especially for democratic South Africa today. Heavy as this might sound to some, Malcolm X asserts

6.Andries Tatane was a man in his early thirties who died during a service-delivery protest in Ficksurg in the Free State province of South Africa. Tatane was shot by the police. There ar a the police. There are a number of similar cases where dogs have been trained on black people. The sad thing is that many of the white police who are involved in these activities derive pleasure from them. that there is still time for black people to become critical of themselves and their contexts with the intention of uniting against the hegemonies that assemble against black people in particular.

The speech in question is about 50 minutes long and covers an array of issues related to the black context of the USA. Whilst Malcolm X asserts his religion as Islam, he is emphatic in suggesting that religion be left in the closet. This is so because he had come to realise that religion at best separates instead of unites. For him, this division interrupts the attention that must be given to the structures and systems that oppress black people in the USA. It is significant on another level to note why he insists that he is still a Muslim (Breitman 2010:39). When this speech was given, Malcolm $X$ was already marginalised by the leader of the Nation of Islam and was in essence gagged from speaking in public. This is what led him to establish his own movement called the Muslim Mosque Inc.

Realising that it was white capitalism which ganged up against black people, Malcolm X (1964a) called for a political Philosophy of Black Nationalism. For him, '... black nationalism only means that the black man (to be understood as mensch) should control the politics and the politicians in his own community'. This is not a diabolical idea as many within the so-called rainbow South Africa would like to believe it to be. To say that the black mensch must control and own the politics of his or her community is a means of self-realisation and autonomy. Once this is achieved, the black mensch will be able to talk with the white mensch as an equal.

\section{Malcolm writes the following:}

\begin{abstract}
... the white man (Mensch) is too intelligent to let someone else come and gain control of the economy of his community. But you [Black people] let anyone come in and take control of the economy of your community, control the housing, control education, control jobs, control the businesses under the pre text that you want to integrate. (Breitman 2010:60)
\end{abstract}

For him, however, Black Nationalism is an attempt to chastise all the folly of the white American civil system and to unify black people against the dictates of the white American Civil system which remains capitalist at best. In a way that speaks directly to the flight of the black self, Malcolm $X$ ridicules what black people are fond of doing once they gain some economic power - fleeing from their real black selves. Malcolm X proposes Black Nationalism as a means of countering that flight from the black self. He puts forward the following argument:

... the political, the economical philosophy of Black Nationalism
only means that blacks have to become involved in a program
of re-education to educate our people into the importance of
knowing that when you spend you dollar out of the community
in which you live, the community in which you spend your
money becomes richer and richer; the community out of which
you take your money becomes poorer and poorer ... the Man is
becoming richer and richer and you become poorer and poorer 
... the community in which you live becomes a slum. It becomes a ghetto. The conditions become run down. And then you have the audacity to complain about poor housing in a rundown community. (Breitman 2010:60f.)

He argued that 1964 was going to be the year of the ballot or the bullet. The reason for his claim was that he was sure that the common black folk have become aware of how hegemonies work. More so, in his assessment, the common black people had become aware of how the black spokespersons for the white hegemonies are used as the intermediaries between the masters and those on the margins. The masses have become disillusioned with these yea-sayers to the hegemonies, and they have become frustrated.

Malcolm X (1964a) put it poignantly when he argues that these younger black men and women:

... have become disillusioned. They have become dissatisfied and all of this has built up frustration in the black communities that makes the black community throughout America today more explosive than all of the atomic bombs the Russians can ever invent. (n.p.)

This is so because politicians are not seen except when it is election year.

For Malcolm, the year 1964 was going to be an explosive year simply because black people had become aware of the trickery of white hegemonies. He intimated the following:

\footnotetext{
$\ldots$ this is the year when all of the white politicians are going to come into the Negro [sic] community. You never see them until election time ... They are going to come with false promises, and they make these false promises they are going to feed our frustration and this will only serve to make matters worse. (Breitman 2010:41)
}

\section{The future of Black Liberation Theology}

The first democratic election in South Africa in 1994 is perceived as the best miracle to have happened to a country fraught with contradictions. Some prefer to see it as creating a clean slate and intentionally prefer to discount the history of the exploitation of black people in this country. I subscribe to a school of thought which is of the view that capitalism and democracy are contradictory. Sampie Terreblanche (2005:16) argues that '... while democracy emphasizes joint interests, equality and common loyalties, capitalism are based on selfseeking inequality and conflicting individual and group interests'. What is more important, notes Terreblanche (2005), is the following:

\footnotetext{
$\ldots$ the legal system that protects both democracy and capitalism is based on the principle of equality before the law, but maintains inequality in the distribution of property rights and opportunities in the capitalist system. (p. 16)
}

For him, the logic of capitalism - given the unequal freedom and unequal rights upon which it is based - goes against the grain of the logic of democracy. It is important for me to point this out simply because democracy is invariably thrown in like a cat amongst the pigeons. We tend to forget about a capitalist and exploitative history which is largely responsible for the current problems and struggle, yet we are willing to defend democracy with our lives if necessary.

Our obsession to want to be relevant and to illustrate that Black Liberation Theology is indeed genuine theology has done tremendous harm to us. We had become alienated from our contexts, and in some instances, we had been assimilated into the very structures of oppression that Black Liberation Theology was struggling against. It must be said outright that there is no future for Black Liberation Theology in South Africa unless this theological enterprise creates its own space and dictate its own terms for its continued relevance and survival. Creating such space and dictating its terms for survival suggest that Black Liberation Theology will continuously have to ask the critical and uncomfortable questions that affect those who are still on the wrong side of history. Today more than ever, Black Liberation Theology must answer the questions of those on the wrong side who want to make sense of what their citizenship means in present-day South Africa if they are not able to gain access to the basic necessities for surviving. Above all, it needs to find ways of helping them reconcile their religious faith with their present situation of need.

We acknowledge that nobody can do for Black Liberation Theology what it must do for itself. We realise that there is a serious contest taking place where Black Liberation Theology is contesting for a space. This space is about engaging critically with the assumption that black people can only participate in the divine design once they have come to terms with what they were designed to be - not totally human.

\section{Is the current context a context for radical politics in South Africa?}

The causes of the frustration of the black masses of which Malcolm X speaks so eloquently are of particular relevance to the South African context. Here as well, politicians are not visible except during an election year when the leadership of the governing political party goes from door to door in search of the votes of the most vulnerable. In South Africa, nothing captures the frustration of ordinary people like service-delivery protests. These protests have escalated since the dawn of democracy in South Africa. ${ }^{7}$

The government of the day is failing the very people whose conditions it is their intention to ameliorate. Ramose captures this game, which is played to garner votes, well in a paper that is soon to be published. The title of his paper reads 'Faces and phases of racism in South Africa' (Ramose 2011:1-11). In this article, Ramose refers to the South African localgovernment elections of May 2011 as 'the toilet elections'.

7.According to Wikipedia (n.d.), South Africa has been dubbed the protest capital of the world and has one of the highest rates of public protest in the world. During the the world and has one of the highest rates of public protest in the world. During the
$2004 / 2005$ financial year, about 6000 protests were officially recorded whilst there were a number of protests which were not reported. 
This name originates from toilets which were build both in areas governed by the Democratic Alliance (DA) and in areas governed by the African National Congress (ANC) (Ramose 2011:3f.). What stood out in particular concerning these toilets was the fact that they were not covered. This means that the human dignity of the people for whom the toilets were built was compromised. If black human dignity was not considered during the local elections, one can only imagine how much more damage will be done to garner votes for the national elections.

The present government of South Africa seems not to be able to deal with the nervous conditions that have been created by white capital. I have argued elsewhere that the nervous condition amongst the majority of black people is primarily the result of two factors: (1) a promise that democracy was going to provide all the privileges that black people had always dreamt of and (2) the depressing realisation that these promises remain unfulfilled for the majority (Tshaka 2010:129). I remain aware of the legacy of apartheid which had made it difficult in some instances to legislate laws that are intentionally aimed at dealing with the divide between rich and poor, which is essentially a divide between white and black people. Language referring to race is not well received in this context because, in the negotiated settlement leading to the 1994 elections, a constitutional democracy was adopted. The South African government therefore finds itself in a tight corner, and crumbs are given to some to create the impression that all is well with a rather sick and generally racist society as the service-delivery protests attests. It is also worth noting that one finds only black people in the service-delivery protests.

The South African context is not unique when it comes to race, and the construction of race was imported to this country from the USA. Writing from her American context, Alexander (2012) argues:

\footnotetext{
... what has changed since the collapse of Jim Crow has less to do with the basic structure of our society than with the language we use to justify it. In the era of colour-blindness, it is no longer socially permissible to use race explicitly as a justification for discrimination, exclusion and social contempt so we don't. (p. 2)
}

The same is true of South Africa. The ANC has adopted a non-racial rhetoric which is flawed and nonsensical as it feeds the very colour-blindness that Alexander (2012) is belabouring. The service-delivery protests clearly suggest that the present government has failed the masses. However, there is a bigger aspect which must not be ignored and that is the economic sphere which, to a large extent, dictates the political direction of this country.

Why are the majority still stuck where they have been more than 20 years ago? The answer lies in the fact that the ANC government and all its African allies have been out-manoeuvred in the Kempton Park negotiations (Terreblanche 2012). This fact is referred to by prominent minds in the South African context. Malcolm puts this out-manoeuvring succinctly when he argues as follows:

... the first thing that the cracker does when he comes in power, he takes all the Negro leaders and invites them for coffee to show that he is alright. And those Uncle Toms cannot pass up the coffee. They come away from the coffee table telling you and me that this man is alright ... (Breitman 2010:43)

This is not a new tactic and was employed in South Africa during the negotiations which had led to the now new South Africa. Gumede speaks about how the ANC was ill prepared to negotiate and how members of the negotiation team where wined and dined (Gumede 2007:79ff.). Having pointed this out, it would be irresponsible of me to suggest that the previous regime was better and had nothing to do with the current inequalities. On the contrary, the previous regime was aware that apartheid was systematic, and they applied it in such a way that the ripple effects would be felt for many more years to come.

The frustration to which Malcolm is referring is unfortunately ill directed in South Africa towards foreigners who are black and especially those who come from other parts of Southern Africa. The competition for sustainable jobs has created a nervous condition for black South Africans as well as Africans from other parts of the continent. This is indeed the racial powder keg of which Malcolm spoke so eloquently in this aforementioned speech. That we have a black government does not suggest that we are not to speak about race anymore. The fact that the ANC prides itself on being an organisation which strives to eradicate racism and sexism does not mean that race is not an issue anymore.

\section{What would Malcolm X say about South Africa today?: A conclusion}

Malcolm X's greatest disappointment was with the very black people who could not see that they were taken for a ride by both dominating political parties in the USA. In the aforementioned speech, he took a swipe at a government which was giving the impression to black people that it had their best interests at heart. Malcom X writes as follows:

Any kind of activity that takes place on the floor of congress or the Senate, it's the government. Any kind of dilly-dallying, that's the government. Any kind of pussyfooting, that's the government. Any kind of act that is signed to delay or deprive you and me right now of getting full rights, that's the government that's responsible. And any time you find the government in a conspiracy to violate the citizenship or civil rights of a people, then you are wasting your time going to that government expecting redress. (Breitman 2010:47)

There can be very little doubt that black people of South Africa are now tired and have come to the conclusion that they cannot find redress from the same government that they have been voting into power since 1994. In their anger and frustration, they are taking to the streets by means of service-delivery protests, some of which are deadly. 
For the sake of comparison, I have to paint a picture of the present-day South African context. It is one which has yet to shed its racist past because apartheid has been structural and systemic. The economic disparities between black and white people are still too glaring. I argued elsewhere that the violence that is perpetrated against some citizens of South Africa is actually perpetrated by the state itself (Tshaka 2010). It is significant to note that this phenomenon is not yet well understood in present-day South Africa. The citizens seem befuddled by the violence that are targeted against Africans from other parts of the continent, yet they cannot see that the nervous conditions were intentionally created by those who are still the real masters of South Africa -the ones who control the economy. We agree with Murphy that black theology (in the past and perhaps even today) has failed to engage capitalism explicitly in its critique of white hegemony (Murphy 2012:28-48).

Whilst the nervous condition is chiefly created by the glaring economic disparity between white and black people, one also has to mention the stereotypes that have become entrenched in the minds of those who are citizens of this country. One of the great contemporary South African poets, Mzwakhe Mbuli, speaks of how it is possible in this country today that black people can be killed by white people whilst being mistaken for baboons and wild pigs. Informed by the current disparities, he laments the fact that it is only black children in South Africa who still learn under trees. That it is only one race - black people wearing blue overalls on the back of pickups in South Africa (Mbuli 2012).

The dawn of democracy brought with it promises which soon turned into huge disappointments. When political organisations were banned during the apartheid era, it was indeed the civic groupings which filled that political vacuum. Gumede (2007:352) is correct in arguing '... that the normalization of south African politics in 1994 saw many once formidable civic groups run out of steam'. One such formidable civic organisation was the South African National Civic Organisation (SANCO).

For a very long time, self-critique of leadership styles was reserved for when comrades were amongst themselves. This was important, given the stereotypes assigned to leaders of African descent by white people. Yet in a context where one is increasingly confronted with matters that are not only a result of structural apartheid but also a result of pure self-interest, a critical theological reflection such as Black Liberation Theology ought to pause and consider whether self-critique is not essential now. The reason for the self-critique is that Black Liberation Theology prides itself on standing with the poor and marginalised in society.

From what can be deduced from the service-delivery protests which have plagued South since the dawn of democracy, it is clear that Black Liberation Theology must become more self-critical. This is so because we are witness to how the ANC has managed to eviscerate all agents that could have played significant roles in keeping it in touch with the masses.

At almost all public opportunities where one would have loved to see an acknowledgement that the struggle against apartheid was a collective one, the ANC has rewritten history and has itself as the only custodian of black people's liberation in South Africa. In essence, it has become an amorphous mess, assimilating all those agents who can keep it honest and attuned to the cries of the most vulnerable who happen to be black. This government is failing its people - that is what Malcolm X would say of it.

Both James Cone (2011) and Michelle Alexander (2012) are adamant that the new Jim Crow is manifested in the incarceration of young black males in present-day USA. I am of the view that neo-apartheid is manifested in the nervous conditions experienced as a result of the lack of basic service-delivery to the most vulnerable in our country.

\section{Acknowledgements}

My elder son, Xolani Theophillus Tshaka, for reminding myself all the time of myself whilst growing up.

\section{Competing interests}

The author declares that he has no financial or personal relationships which may have inappropriately influenced him in writing this article.

\section{References}

Alexander, M., 2012, The new Jim Crow: Mass incarceration in the age of colour-blindness, The New Press, New York.

Boesak, A.A., 1984, Black and reformed: Apartheid, liberation and the Calvinist tradition, Orbis Books, Maryknoll.

Breitman, G. (ed.), 2010, Malcolm X speaks, Pathfinder, New York.

Cone, J., 1992, Martin and Malcolm in America: A dream or a nightmare, Orbis, Maryknoll.

Cone, J., 2011, The cross and the lynching tree, Maryknoll, Orbis books.

Cruze, H., 1964, The crisis of the Negro intellectual, New York Review of Books, New York.

Fanon, F., 1965, Concerning violence, Penguin Books, New York.

Ford, D. (ed.), The modern theologians, 2nd edn., pp. 445-454, Blackwell Publishers, Massachusetts.

Forgacs, D. (ed.), 2000, The Antonio Gramsci reader: Selected writings 1916-1935, New York Press, New York.

Giliomee, H., 2004, Rediscovering and re-imagining the Afrikaners in a new South Africa: Autobiographical notes on writing an uncommon biography, Grafaria, Leiden.

Gumede, W., 2007, Thabo Mbeki and the battle for the soul of the ANC, Zed Books, London.

Malcolm X., 1964a, The ballot or the bullet, CD, Cleveland, Ohio.

Malcolm X., 1964b, Malcolm X speaks, CD, Harlem, New York.

Mbiti, J., 1993, 'An African views American Black Theology', in J. Cone \& G. Wilmore (eds.), Black theology: A documentary history, vol. 1: 1966-1979, pp. 379-384, Orbis books, Maryknoll.

Mbuli, M., 2012, Amandla: Struggle songs ... songs of freedom, CD, CCP Records Co., Johannesburg.

Murphy, T., 2010, 'The influence of socialism in Black and Womanist theologies: Capitalism's relationship as source, sin and salvation', Black Theology: An International Journal 10(1), 28-48. http://dx.doi.org/10.1558/blth.v10i1.28

Oates, S.B., 1994, Let the trumpet sound: A life of Martin Luther King, JR., Harper Collins Publishers, New York. 
Ramose, M.B., 2011, 'Faces and phases of racism in South Africa', paper given at an international conference organized by the Transatlantic Roundtable on Religion and Race, 03-06, July.

Religion in Public Life n.d., 'Multi-Event 1999: Transforming public life: Religion in the making of cultural values and public policy', viewed 01 August 2012, from http://web.uct.ac.za/depts/ricsa/confer/me99/me99_in.htm

Terreblanche, S., 2005, A history of inequality in South Africa: 1652-2002, University of Natal Press, Pietermaritzburg.

Terreblanche, S., 2012, Lost in transformation: South Africa's search for a new future since 1986, KMM Review Publishing Company, Sandton.
Tshaka, R.S., 2010 'Do our theological methodologies help us to deal with situations of violence in black communities, specifically Afrophobia?', Journal of Theology in Southern Africa 138, 124-135.

Tshaka, R.S. \& Makofane, M.K., 2010, 'The continued relevance of Black Liberation Theology for democratic South Africa today', Scriptura 105(3), 532-546.

Villa-Vicencio, C., 1992, A theology of reconstruction: Nation building and human rights, Cambridge University Press, Cambridge. http://dx.doi.org/10.1017/ CBO9780511607592

Wikipedia n.d., 'Protests in South Africa', viewed n.d., from http://en.wikipedia.org/ 